УДК $327(73+510+470)$

DOI: $10.26693 /$ ahpsxxi2020.02.055

\title{
GEOPOLITICAL AND REGIONAL CONSIDERATIONS: US, CHINA AND, RUSSIA: PARTNERS OR COMPETITORS?
}

\author{
Anatoliy Khudoliy, \\ e-mail: toliy65@yahoo.com \\ ORCID: https://orcid.org/oooo-Ooo1-8144-126X \\ National University of Ostroh Academy, Ostroh, Ukraine
}

The article deals with the policy of the United States of America, Peoples' Republic of China (PRC) and the Russian Federation in the Asia-Pacific Region. Leadership ambitions of the countries became evident in political, economic, military, technological and space spheres especially over the last few years.

The purpose of the article is to analyze American-Chinese and Russian-Chinese relationships in the Asia-Pacific and identify reasons for their foreign policy course. Both countries, China and the USA are eager to play leader's part in the regional politics. The relationships between the PRC and the United States significantly deteriorated, especially during D. Trump presidency.

The author draws attention to the US policy and its attempts to strengthen its own positions in the region as well as to China's economic activity reflected in transport projects, for instance - One Belt, One Road initiative, perceived by Washington as a challenge to its leader's position. Tensions between two countries increased due to aggressive regional policy of China which claimed sovereignty over few small islands in the South China Sea. Beijing and Washington compete for leadership in the sphere of technology where China is ahead of the USA.

Keywords: the APR, the USA, China, Russia, leadership, regional policy, regional actors

Introduction. The Asia-Pacific region (APR) is a region of fast economic development with bright perspectives for future. That's' why it draws attention of so many regional and geopolitical actors, especially the USA and the RF. The United States have five ally treaty partners in the Asia-Pacific region. Among them: Australia, Japan, the Philippines, South Korea, and Thailand. At the same time 4 Asian economies were among the top 10 U.S. trading partners in 2017: China (no. 1), Japan (no. 4), South Korea (no.6) and India (no.9). Asia includes five nations with nuclear weapons arsenals: China and Russia as permanent members of the UN Security Council; India and Pakistan, which are bitter rivals; and North Korea ${ }^{1}$.

Topicality of the research. Scholars recognize fundamental changes in the world politics. But the changes are impossible to imagine without the key actors, such as the United States, China and the Russian Federation which significantly affect international and regional politics. Over the last few years the rise of China and aggressive policy of Russia challenge foreign policy of the USA. Recent events such as US-China trade war, Russian aggression in the East of Ukraine and occupation of the Crimea have increased the need for thorough analysis of relationships between the USA and China, the USA and the RF in order to predict the consequences of the political and economic confrontation. So the topicality of the article is defined by its relevance to the relationships among the USA, China and Russia in political, economic and security issues.

${ }^{1}$ Chanlett-Avery, E., Kronstadt, A.K., Lawrence, S.V. \& Manyin, M.E. (2018, December 14). The Asia Pacific: Challenges and Opportunities for U.S. Policy Federation of American Scientists (FAS). Retrieved from https://fas.org/sgp/crs/row/IF11047.pdf 
The article explores political, economic and security activities of the USA, China and Russia while considering their strong leadership ambitions and foreign policy goals in the Asia-Pacific region. It is intended to achieve two principal objectives regarding Asia-Pacific regional leadership. First, we want to analyze foreign policy of the USA, China, and Russia from the point of view of protecting and advancing their vital interests in the region. And the second consideration is to identify ambitions and some of the motives of the regional actors.

Literature review. Foreign policy of the United States, China and the Russian Federation has been analyzed by numerous scholars who paid attention to different aspects of the problem. Among them were western, Ukrainian and Russian scholars. Traditionally studies range from regional security issues to economic interests of the countries. In the past decade scholars thoroughly investigated China's leader's ambitions in the Asia-Pacific region (J. Stavridis, A. Chatzky and J. McBride, K. Rapoza, B. Lendon); the United States plans to dominate in the APR (D. Paal, E. Kania), USChina trade disputes (P. Wiseman, Z. Miller and C. Lucey, S. Lendman) or Russia's initiatives to strengthen friendly relations with China in the region (B. Lo, S. Fortescue).

Main body. From the point of view of regional leadership two countries pretend to lead there - the USA and China. Each of them has reasons to do it. Historical context says that relationships between these two countries sustained ups and downs. Among areas of contention were China's territorial claims for the islands in the East China Sea; support for North Korea's Kim Jong-un, who launched ballistic missiles over the Japanese islands; alleged hacks into Tokyo's intelligence and military command systems; and the intellectual theft ${ }^{2}$.

In 2012 there were trade tensions between the USA and China. The USA and the EU had talks with China at the WTO over its restrictions on exporting rare earth metals. The United States and its allies stressed that China's quota violated international trade norms. China called it unfair and decided to defend its rights in trade disputes. Despite B. Obama's attempts to ease tense U.S.-China relations they deteriorated in 2015 when U.S. Secretary of Defense Ashton Carter called on China to halt its controversial land reclamation efforts in the South China Sea. D. Trump promised to honor the One China policy while conversing with Chinese President Xi Jinping. In March of 2018 the Trump administration announced sweeping tariffs on Chinese imports. The situation with trade deteriorated in May of 2019. In August of 2019 after China's central bank let Yuan weaken significantly, the Trump administration called China a currency manipulator3.

B. Obama was conducting consistent foreign policy developing ties with Asian partners and allies within Trans-Pacific Partnership. The Trump administration approach was less consistent in comparison with his predecessor, because D. Trump attempted to strengthen relations with Asia-Pacific countries on a bilateral basis 4 .

The tensions that appeared in relations between China and other countries as a result of the aggressive China's policy in the South China Sea pushed Washington to apply a tough approach expanding freedom of navigation operations. It also took a decisive position against China's anticompetitive trade practices. In order to strengthen its own position the Trump administration rolled out a broad strategy for the region under the title «the Free and Open Indo-Pacific». It promoted a rules-

\footnotetext{
${ }^{2}$ Stavridis, J. (2019, February 22). China's steady plan to take control of the Asia-Pacific region. Financial Review. Retrieved from https://www.afr.com/world/chinas-steady-plan-to-takecontrol-of-the-asiapacific-region-20190222-h1bl57

3 Council on Foreign Relations (2020). U.S. Relations With China 1949-2019. Retrieved from https://www.cfr.org/timeline/us-relations-china

4 Chatzky, A. \& McBride, J. (2019, February 21). China's Massive Belt and Road Initiative. Council on Foreign Relations. Retrieved from https://www.cfr.org/backgrounder/chinas-massive-beltand-road-initiative
} 
based security and economic order in Asia, while also encouraged closer cooperation among regional U.S. partners5.

Political motives are determined by China's position as the US largest banker which gives Beijing some political advantages. Even in the position of a harsh trade confrontation China threatens to sell part of its debt holdings. It would undermine American economy. Another means is an attempt of China to make Yuan a world currency. Beijing often calls for a new global currency to replace the dollar, which is used in most international transactions. As soon as the USA allows the value of the dollar drop this will make the debt China holds less valuable ${ }^{6}$.

Economic interests are vital for all regional and world actors, so the above mentioned countries over the last decade tried to increase economic influence in the region. China envisaged One Belt, One road (OBOR) policy; the China-Mongolia-Russia Economic Corridor (CMREC); New Eurasian Land Bridge (NELB); The China-Central Asia-West Asia Economic Corridor (CCWAEC); the China-Indochina Peninsula Economic Corridor (CICPEC); the China-Pakistan Economic Corridor (CPEC); the Bangladesh-China-India-Myanmar Economic Corridor (BCIMEC).

China's Belt and Road Initiative launched in 2013 strengthened ties with many countries of the world. It turned out to be successful. Being effectively implemented, it extended to 65 countries with GDP of $\$ 23$ trillion7. Another initiative, the so called China-Mongolia-Russia Economic Corridor, was initiated in 2014 during the meeting in Dushanbe (Tajikistan). The participants (China, Mongolia and Russia) focused predominantly on transport ${ }^{8}$. New Eurasian Land Bridge became a long rail link connecting China with more than 30 countries and regions.

China's thirst for numerous routes comes from the profit motives. New routes are important because they enhance the range of transport options and reduce hold-up possibilities. On the other hand, they save transport times in comparison with construction of a rail line, so China combines two options to determine the better cost trade-off. So, Beijing is promoting a grand industrial policy while Americans see it as a direct challenge to U.S. technological superiority.

The United States of America is pursuing a leadership agenda in the region. So Washington set few key tasks for this purpose. First, it was eager to create a coalition of values and interests that would be flexible and adaptive to changing circumstances. Second, it attempted to unite efforts of both countries for mutual benefit. Third, it was eager to put up effective defenses against coercive behavior when necessary9.

The center of economic activity shifted to Asia-Pacific in 1990s. According to statistics, since 1991, the Asia-Pacific economic size has more than tripled, and trade between Asia and the United States has grown more than 200 percent ${ }^{10}$. Cooperative

5 Council on Foreign Relations (2018, November 14). Making U.S.-Vietnam Ties a Model for Free and Open Indo-Pacific. Retrieved from https://www.cfr.org/report/making-us-vietnamties-model-free-and-open-indo-pacific

${ }^{6}$ Amadeo, K. (2019, August 1). US Debt to China, How Much It Is, Reasons Why, and What If China Sells. The Balance. Retrieved from https://www.thebalance.com/u-s-debt-to-china-howmuch-does-it-own-3306355

7 Center for Strategic and International Studies (2019, May 29). How will the Belt and Road initiative advance China's interests? Retrieved from https://chinapower.csis.org/china-belt-androad-initiative/

8 Backgrounder: Economic corridors under Belt and Road initiative (2017, May 9). Global times. Retrieved from http://www.globaltimes.cn/content/1046027.shtml

9 Paal, D. (2019, January 31). America's Future in a Dynamic Asia. Carnegie Endowment for International Peace. Retrieved from https://carnegieendowment.org/2019/01/31/america-sfuture-in-dynamic-asia-pub-78222

${ }^{10}$ U.S. Census Bureau (2018, July 19). Trends in trade: U.S. - China Goods Trade 2012-2017. Retrieved from https://www.uscc.gov/sites/default/files/Research/ Trends\%2oin\%2oTrade\%20Staff\%2oReport.pdf 
efforts of regional actors led to evolving of a number of political and economic organizations. Among them the Association of Southeast Asian Nations, Asian Pacific Economic Cooperation, the South Asian Association for Regional Cooperation, the South Pacific Forum and the Commonwealth of Nations.

Due to intensification of trade and economic activity tensions in the region increased. American politicians accused China of unfair trade practices. Among them: subsidies for Chinese exporters, manipulations with its currency, dumping steel and other products onto American market. Among other unfair practices they identified giving their domestic businesses an advantage in overseas trade ${ }^{11}$.

Despite all the official statements economic confrontation was inevitable. In 2018 American actions taken against China's turned into a trade war. The trade confrontation increased the US trade deficit with China to $\$ 55.5$ billion, its highest level in 10 years ${ }^{12}$. Unfortunately, the damage from Trump's trade war with China is significant and global markets have become increasingly volatile ${ }^{13}$.

B. Obama during his presidential terms treated trade deals as a priority in his foreign policy course because he was convinced that this kind of deal would strengthen American position in the Asia Pacific region. The situation changed after D. Trump victory in the elections. The deal was expected to be ratified (by February 2018), but in 2017 Trump signed an executive order withdrawing the USA from the Trans-Pacific Partnership ${ }^{14}$. America's step made Asian countries negotiate new regional trade agreements. In September 2018, the United States and Japan agreed to open limited trade negotiations ${ }^{15}$.

Fierce competition between the USA and China is observed in the sphere of technology. Beijing invests a lot in technology and seeks to be ahead of the USA. And the new frontier for both countries is Artificial Intelligence (AI) and quantum computing. Experts say that if China overtakes the United States in AI it would boost economic growth and change the entire character of warfare ${ }^{16}$. High technologies can improve autonomous systems, war gaming and information processing ${ }^{17}$.

Beijing invested $\$ 10$ billion in the research center for quantum applications. It is pursuing a key goal - building a quantum computer which is useful for producing highly accurate, self-contained navigation systems, which is a key application for autonomous vehicles and submarines. The success of the project will allow Beijing to build a nationwide quantum network for military communications ${ }^{18}$. The United States

${ }^{11}$ Third Way. (2019, March 7). 2019 Country Brief: China. Retrieved from https://www.thirdway.org/primer/2019-country-brief-china

12 Rapoza, K. (2018, December 10). Trade War Update: China Subverts Tariffs, Trade Gap Gets Wider. Forbes. Retrieved from https://www.forbes.com/sites/kenrapoza/2018/12/10/trade-warupdate-china-subverts-tariffs-trade-gap-gets-wider/\#732b 105950e5

${ }_{13}$ Stevenson, A. (2018, December 10). Wall St. Rises in Day of Unsteady Trading as Global Markets Drop. The New York Times. Retrieved from https://www.nytimes.com/2018/12/10/business/global-markets-wall-street.html

${ }_{14}$ Taylor, A. (2018, April 13). A timeline of Trump's complicated relationship with the TPP. The Washington Post. Retrieved from https://www.washingtonpost.com/news/worldviews/ $\mathrm{wp} / 2018 / 04 / 13 /$ a-timeline-of-trumps-complicated-relationship-with-the-tpp/

15 Chanlett-Avery, E., Kronstadt, A.K., Lawrence, S.V. \& Manyin, M.E. (2018, December 14). The Asia Pacific: Challenges and Opportunities for U.S. Policy Federation of American Scientists (FAS). Retrieved from https://fas.org/sgp/crs/row/IF11047.pdf

${ }^{16}$ Colin, C. (2017, November 1). Our Artificial Intelligence 'Sputnik Moment' is Now: Eric Schmidt and Bob Work. Breaking Defense. Retrieved from https://breakingdefense.com/2017/11/ourartificial-intelligence-sputnik-moment-is-now-eric-schmidt-bob-work/

${ }^{17}$ Kania, E. (2017, November 28). Battlefield Singularity: American Intelligence, Military Revolution, and China's Future Military Power. Center for a New American Security. Retrieved from https://s3.amazonaws.com/files.cnas.org/documents/Battlefield-Singularity-November-

2017.pdf? mtime $=20171129235805$

${ }^{18}$ Lin, J. \& Singer, P.W. (2017, October 10). China is opening a new quantum research supercen- 
has no similar projects in action which diminishes military capabilities of Washington and gives Beijing additional technological, financial and military advantages.

No doubt, that technological advantage is the core of US military power, but Chinese efforts can lead to a scientific and a technological superiority. Being on the leading edge of the developing of Artificial Intelligence and a quantum computer China demonstrates its ambition to overtake America as superpower.

Space is another sphere of confrontation. By words of experts, Russia and China will continue to expand their space-based reconnaissance, communications and navigation systems in terms of numbers of satellites, breadth of capability and applications for use ${ }^{19}$.

Military issues also affect the climate of the Asia-Pacific region. China is challenging the United States' military dominance in the region and this situation worries American allies such as South Korea and Japan, because it risks a regional arms race. In the twenty first century China made a substantial economic and military leap that allowed it to challenge the USA ${ }^{20}$. Every year for two decades, China's military budget increased by double digits, reaching $\$ 175$ billion in $2018^{21}$. In comparison with the rest of the world China is the second in military spending and left Russia and other countries, such as India (3.3\%), Japan (2.7\%) and South Korea (2.2\%) behind.

China has regional ambitions and it is quite logical due to its power, economy, military, territory etc. At the same time, its rise and strengthening pose some challenges for the United States: 1) a standoff in the South China Sea; 2) China is becoming military aggressive (including nuclear weapon) and the USA can serve as a counterbalance to it in developing partnership with its allies; 3) China is heavily investing in technologies.

Asian nations, U.S. allies and partners, are involved in major territorial disputes with China in the South China Sea and East China Sea, as well as along the India-China and India Pakistan borders. The South China Sea is a critical world trade route and a potential source of resources, particularly natural gas. By estimates, there are 11 billion barrels of oil and 190 trillion cubic feet of natural gas ${ }^{22}$ in the region which. No doubt, China wants to dominate the South China Sea, rejecting the claims of neighboring countries such as Vietnam, Malaysia, Taiwan, Brunei and the Philippines. For a long time Chinese military vessels were intimidating Vietnamese, Filipino and Japanese fishermen and commercial vessels over the territory in the South China Sea pumping up the pressure. But within time the conflict continued to grow. China has gradually built facilities on these islands that could quickly be adopted for military use ${ }^{23}$. It has is pursuing a triple purpose to intimidate neighboring countries, and expel the USA, because it is more difficult for Washington to operate in the region during a conflict and to form a buffer zone around China.

Threatened by economic and military rise of China Asia Pacific countries started to increase military budgets and military buildup. Japan revised the pacifist constitution

ter. Popular Science. Retrieved from https://www.popsci.com/chinas-launches-new-quantumresearch-supercenter/

${ }^{19}$ Garamone, J. (2018, February 13). Cyber Tops List of Threats to U.S., Director of National Intelligence Says. US Department of Defense. Retrieved from https://www.defense.gov/Newsroom/News/Article/Article/1440838/cyber-tops-list-of-threatsto-us-director-of-national-intelligence-says/

20 Third Way. (2019, March 7). 2019 Country Brief: China. Retrieved from https://www.thirdway.org/primer/2019-country-brief-china

${ }^{21}$ Lendon, B. (2018, March 6). China boosts military spending $8 \%$ amidst ambitious modernization drive. CNN. Retrieved from https://edition.cnn.Com/2018/03/04/asia/chinese-militarybudget-intl/index.html

${ }^{22}$ The US Energy Information Administration. (2013, February 7). South China Sea. Retrieved from https://www.eia.gov/beta/international/regionstopics.php?RegionTopicID=SCS

${ }_{23}$ Center for Strategic and International Studies (CSIS). (2020, September 4). Asian Maritime Transparency Initiative. Retrieved from https://amti.csis.org/ 
and began building up its armed forces; the USA, by agreement with the Philippines, decided to strengthen its military presence and deploy more militaries on five bases in the Philippines ${ }^{24}$.

Despite fears about China's strength and aggression, the Unites States still remains an essential power to the stability in the region. So, despite shifts with China, Washington is not going to lose its positions and influence in the region. At the $6^{\text {th }}$ U.S. - ASEAN Summit Vice President Pence stressed: «We all agree that empire and aggression have no place in the Indo-Pacific»25.

Despite traditional arms China is intended to diversify and grow its nuclear weapons. So, it started its ballistic missile programs which can pose a serious threat to the United States, Japan, the Philippines and South Korea in case the military conflict 26 . The Report represented by Rand Corporation in 2017 postulates the idea that accelerated nuclear buildup and establishing a Chinese Missile Defense System affect not only nuclear policy and status of the country, but also regional and geostrategic policy of Beijing. China foreign policy course proves the idea that it is eager to get strategic advantages first of all in the Asia Pacific ${ }^{27}$.

Representatives of military circles are convinced that Washington should rearm and redeploy military forces from the Middle East to the Asia-Pacific in order to meet the emerging challenges ${ }^{28}$. Other experts, both realists and liberal internationalists support the idea that U.S. should disengage from former positions of preeminence in the AsiaPacific and pulled back to locations beyond the reach of China's new weapons systems ${ }^{29}$.

American regional and geopolitical stance on China and Russia was presented in the U.S. National Security Strategy (2017) and the National Defense Strategy (2018) where both countries are called potential threats $3^{\circ}$. China, by estimates of the US Department of Defense, implementing military modernization lays the foundation for reordering the Indo-Pacific region to its advantage. It seeks regional hegemony in the short term and displacement of the United States to achieve global preeminence in the future ${ }^{3}$.

Russia has always been active in the Asia Pacific region. Recent steps made in the region indicate that Moscow is pursuing a multi-dimensional approach towards the region: 1) reinforcing the partnership with China; 2) reaching out to other major players; 3) promoting itself as a significant security and economic contributor 32 . The

\footnotetext{
${ }^{24}$ Mogato, M. (2017, January 26). Philippines says U.S. military to upgrade bases, defense deal intact. Reuters. Retrieved from https://www.reuters.com/article/us-philippines-usadefence/philippines-says-u-s-military-to-upgrade-bases-defense-deal-intact-idUSKBN15A18Z

25 White House. (2018, November 14). Remarks by Vice President Pence at the $6^{\text {th }}$ U.S.-ASEAN Summit. Retrieved from https://www.whitehouse.gov/briefings-statements/remarks-vicepresident-pence-6th-u-s-asean-summit/

${ }^{26}$ Heginbotham, E., et al. (2017). China's evolving nuclear deterrent: major drivers and issues for the United States. Rand Corporation. Retrieved from https://www.rand.org/pubs/research_reports/RR1628.html

${ }_{27}$ Chatzky, A. \& McBride, J. (2019, February 21). China's Massive Belt and Road Initiative. Council on Foreign Relations. Retrieved from https://www.cfr.org/backgrounder/chinas-massivebelt-and-road-initiative

${ }^{28}$ Weber, R.N. (2005, September 9). Military-Industrial Complex. Encyclopedia Britannica. Retrieved from https://www.britannica.com/topic/military-industrial-complex

29 Paal, D. (2019, January 31). America's Future in a Dynamic Asia. Carnegie Endowment for International Peace. Retrieved from https://carnegieendowment.org/2019/01/31/america-sfuture-in-dynamic-asia-pub-78222

$3^{30}$ Core National Security Strategy Documents of the USA (2018). National Defense Strategy of the United States of America, 4. Retrieved from https://www.bits.de/NRANEU/others/strategy.htm\#security ${ }^{31}$ Ibid, 2.

$3^{2}$ Lo, B. (2019, August). Once more with feeling: Russia and the Asia-Pacific. Analysis. Lowy Institute, 1. Retrieved from http://www.lowyinterpreter.org/publications/once-more-feelingrussia-and-asia-pacific
} 
term Indo-Pacific, used by D. Trump, is not appropriate for Russian policy in the region due to the following reasons: 1) Moscow is more interested in the Asia-Pacific than in the Indian subcontinent; 2) India is less important for Russia in comparison with China. The RF is eager to play more influential role in the Asia Pacific, but its strategy is not always successful.

Moscow had long, hard, and challenging relations with Beijing. Among them: 1) a Sino-Soviet split; 2) a sensitive issue of the Russian Far East33; 3) China and Russia share a long and common border that stimulates both countries to find compromises and cooperate despite past confrontations and suspicions. On the other hand China is interested in close relations with Russia, looking through the border at rich in mineral resources of eastern territories of Russia.

The level of cooperation between two countries nowadays is unprecedented. Cooperation with China is a sensitive issue for the Russian Federation, so economic ties increased over the last few years. Delivering speech to the Federal Assembly in 2019 V. Putin singled out China, India, Japan and ASEAN countries as partners to have close and robust relations ${ }^{34}$. Moscow was trying to develop regional political and security framework in its own interests.

Under the burden of imposed sanctions and the limited access to Western technologies and finances Moscow was made to develop ties with China. Alexander Gabuev of Moscow's Carnegie Center discussing the change of the relationship noted that the Russians removed three key barriers to a close relationship: a truce and cooperation with China in Central Asia; renewed arms sales; and ending the ban on China's involvement in resource projects35.

Each country considers the other a reliable political, economic, financial, trade, and military partner. Beijing has become Russia's leading economic partner, and Moscow has overtaken Saudi Arabia to be the number one source of Chinese oil imports ${ }^{36}$.

At the same time, Russia positions itself as a link between Asia Pacific and Europe; as a major supplier of energy resources and agricultural products. It continued to advocate a strategic proposal to connect the trans-Korean railway with Russia's TransSiberian railway, forming a strategic link between western European and Russian industrial and transport hubs with South Korean ports37.

2018 was favorable for Russia and China from the perspective of improving relations. Both countries were anxious about the American THAAD missile defense system in South Korea. In July 2016, American and South Korea military officials agreed to deploy the THAAD missile defense system in the country to counter North Korea's growing threats. In 2018 President Trump announced American intention to withdraw from 1987 Intermediate-range Nuclear Forces (INF) treaty. In February 2019 Donald Trump confirmed that the US is leaving the INF treaty, saying "we will move forward with developing our own military response options» to Russia's suspect

\footnotetext{
33 Fortescue, S. (2017, March 23). Russia's activities and strategies in the Asia-Pacific, and the implications for Australia, 3. Retrieved from https://www.aph.gov.au/About_Parliament/Parliamentary_Departments/Parliamentary_Library/pubs/Vis/vis1617/RussiaAsiaPacific 34 Muraviev, A. (2019, May 6). Understanding Russia's Strategic Engagement with the Indo-AsiaPacific. Asia Pacific Bulletin, 475. Retrieved from https://www.eastwestcenter.org/publications/understanding-russia\%E2\%80\%99s-strategicengagement-the-indo-asia-pacific

35 Gabuev, A. (2016, June 29). Friends with Benefits? Russian-Chinese Relations After the Ukraine Crisis. Carnegie Moscow Center. Retrieved from https://carnegie.ru/2016/06/29/friends-with-benefits-russian-chinese-relations-after-ukrainecrisis-pub-63953

${ }^{36}$ Russia Remains China's Largest Crude Oil Source for 3rd Year: Report. (2019, March 24). Global Times. Retrieved from http://www.globaltimes.cn/content/1143223.shtm

37 Muraviev, A. (2019, May 6).
} 
missile ${ }^{8}$. The statements regarding the 1987 INF raised anxiety of China and Russia and pushed both of them to closer ties and cooperation.

In order to have closer ties with the Asia Pacific countries and conduct more proactive policy in Asia, Russia participated in the Eastern Economic Forum (EEF). The EEF is an instrument for enhancing Russia's economic cooperation with its Asian neighbors in the Russian Far East. Now it is turning into an important international venue for discussions on regional political and security issues39.

Since Trump inauguration China and Russia have demonstrated signs of solidarity. Russian President V. Putin and Xi seem to thrive off each other in their many meetings. Even the unprecedented Vostok-18 joint military exercise in August 2018 was held in cooperation between the two countries to new heights40.

Russia also strengthened its military position in the Asia-Pacific region. By 2020 forces of the Eastern Military District got more than 7,980 items of new and upgraded armaments and heavy equipment.

Russia demonstrates its military power in different ways. From August to midSeptember 2018, the Russian military carried out the Vostok 2018 strategic maneuvers and war games. The exercises signaled that Russia is preparing for a possible confrontation with a big, technically sophisticated military force, reinforcing Putin's perceived intention to reassert Russia's status as a global power.

Russia's growing strategic cooperation with China should be considered. Chinese military troops use every opportunity to learn from Russian armed forces. Chinese military troops participated in military exercises 'Vostok 2018' under Russian command with the purpose to learn first-hand from Russian experienced military forces ${ }^{41}$. Apart from military cooperation with Beijing, Moscow sells arms in the Asia Pacific. According to SIPRI Arms Transfers Database, Russia is number two world exporter in the global share of major arms exports (2014-2018) ${ }^{42}$. Russian weapons exported to Asian countries allow their users to deploy advanced military capabilities. Along with close security and defense relations, Moscow is interested in developing international defense and security cooperation with small countries such as Sri-Lanka and Fiji.

Conclusions. It's quite evident that China challenges the United States dominance in the Indo Pacific and in the world. To deter dominance of Beijing in military sphere Washington develops more close relations with its Asian partners and allies, strengthening them economically and military. It presupposes economic, political and military assistance to the Indo-Pacific countries. Only under such circumstances the United States of America will be able to respond to Chinese aggression against American allies in the region if it occurs. Washington will neither refuse to play a dominant role in the Indo-Pacific region, nor around the world, so to survive and maintain the lead over China and other superpowers it has to invest in technologies, strengthen military capabilities and develop economy.

From the point of view of leadership China is seeking to strengthen its regional

\footnotetext{
${ }^{38}$ Borger, J. (2019, February 1). Donald Trump confirms US withdrawal from INF nuclear treaty. The Guardian. Retrieved from https://www.theguardian.com/world/2019/feb/o1/inf-donaldtrump-confirms-us-withdrawal-nuclear-treaty

39 Koldunova, E. (2019). Russia and Turbulent Waters of the Indo-Pacific. In Huisken, Ron (Ed.). Regional Security Outlook. Council for Security Cooperation in the Asia Pacific (p. 20). Retrieved from http://www.cscap.org/uploads/docs/CRSO/ CSCAP\%202019\%20Regional\%20Security\%20Outlook.pdf

40 Grove, Th. (2018, August 28). Russian Troops Gear Up for Massive War Games With Chinese Military. The Wall Street Journal. Retrieved from https://www.wsj.com/articles/russian-troopsgear-up-for-massive-war-games-with-chinese-milita ry-1535466282

${ }_{41}$ Muraviev, A. (2019, May 6).

${ }^{42}$ Frohlich, Th. (2019, March 11). The World's Biggest Arms Dealers and Their Biggest Clients. 24/7 Wall Street. Retrieved from https://247wallst.com/special-report/2019/03/11/the-worldsbiggest-arms-dealers-and-their-biggest-clients/2/
} 
position and its territorial claims sound strong despite the shifts with other regional actors. It is in the interests of the United States to develop habits of negotiation and cooperation rather than dictation or confrontation. By the same token, the United States will need to find a pragmatic basis for bilateral relations with China that protects what is working and helps adjust what is not.

In the security domain, the United States should reinforce its review of the country's military dispositions and doctrines in the Asia Pacific. On the economic front, trade problems need cooperation with other states to create incentives and disincentives for China to reduce its mercantilist tendencies.

\section{REFERENCES}

Amadeo, K. (2019, August 1). US Debt to China, How Much It Is, Reasons Why, and What If China Sells. The Balance. Retrieved from https://www.thebalance.com/u-s-debt-to-chinahow-much-does-it-own-3306355 [in English].

Borger, J. (2019, February 1). Donald Trump confirms US withdrawal from INF nuclear treaty. The Guardian. Retrieved from https://www.theguardian.com/world/2019/feb/o1/infdonald-trump-confirms-us-withdrawal-nuclear-treaty [in English].

Chatzky, A. \& McBride, J. (2019, February 21). China's Massive Belt and Road Initiative. Council on Foreign Relations. Retrieved from https://www.cfr.org/backgrounder/chinasmassive-belt-and-road-initiative [in English].

Chanlett-Avery, E., Kronstadt, A.K., Lawrence, S.V. \& Manyin, M.E. (2018, December 14). The Asia Pacific: Challenges and Opportunities for U.S. Policy Federation of American Scientists (FAS). Retrieved from https://fas.org/sgp/crs/row/IF11047.pdf [in English].

Colin, C. (2017, November 1). Our Artificial Intelligence 'Sputnik Moment' is Now: Eric Schmidt and Bob Work. Breaking Defense. Retrieved from https://breakingdefense.com/2017/11/ourartificial-intelligence-sputnik-moment-is-now-eric-schmidt-bob-work/ [in English].

Fortescue, S. (2017, March 23). Russia's activities and strategies in the Asia-Pacific, and the implications for Australia. Parliament of Australia. Retrieved from https://www.aph.gov.au/About_Parliament/Parliamentary_Departments/Parliamentary_Li brary/pubs/Vis/vis1617/RussiaAsiaPacific [in English].

Frohlich, Th. (2019, March 11). The World's Biggest Arms Dealers and Their Biggest Clients. 24/7 Wall Street. Retrieved from https://247wallst.com/special-report/2019/03/11/theworlds-biggest-arms-dealers-and-their-biggest-clients/2/ [in English].

Gabuev, A. (2016, June 29). Friends with Benefits? Russian-Chinese Relations After the Ukraine Crisis. Carnegie Moscow Center. Retrieved from https://carnegie.ru/2016/06/29/friends-with-benefits-russian-chinese-relations-afterukraine-crisis-pub-63953 [in English].

Garamone, J. (2018, February 13). Cyber Tops List of Threats to U.S., Director of National Intelligence Says. US Department of Defense. Retrieved from https://www.defense.gov/Newsroom/News/Article/Article/1440838/cyber-tops-list-ofthreats-to-us-director-of-national-intelligence-says/ [in English].

Grove, Th. (2018, August 28). Russian Troops Gear Up for Massive War Games With Chinese Military. The Wall Street Journal. Retrieved from https://www.wsj.com/articles/russiantroops-gear-up-for-massive-war-games-with-chinese-milita ry-1535466282 [in English].

Heginbotham, E., et al. (2017). China's evolving nuclear deterrent: major drivers and issues for the United States. Rand Corporation. Retrieved from https://www.rand.org /pubs/research_reports/RR1628.html [in English].

Kania, E. (2017, November 28). Battlefield Singularity: American Intelligence, Military Revolution, and China's Future Military Power. Center for a New American Security. Retrieved from https://s3.amazonaws.com/files.cnas.org/documents/Battlefield-SingularityNovember-2017.pdf?mtime $=20171129235805$ [in English].

Koldunova, E. (2019). Russia and Turbulent Waters of the Indo-Pacific. In Huisken, Ron (Ed.). Regional Security Outlook. Council for Security Cooperation in the Asia Pacific. (pp. 18-20). Retrieved from http://www.cscap.org/uploads/docs/CRSO/ CSCAP\%202019\%20Regional\%20Security\%20Outlook.pdf [in English].

Lendman, S. (2019, August 8). Escalating U.S. war on China by other means. Undermining stability in Asia-Pacific region. Global Research. Retrieved from https://www.globalresearch.ca/escalating-us-war-china-other-means/5685952 [in English]. 
Lendon, B. (2018, March 6). China boosts military spending 8\% amidst ambitious modernization drive. CNN. Retrieved from https://edition.cnn.Com/2018/ 03/04/asia/chinese-military-budget-intl/index.html [in English].

Lin, J. \& Singer, P.W. (2017, October 10). China is opening a new quantum research supercenter. Popular Science. Retrieved from https://www.popsci.com/chinas-launches-newquantum-research-supercenter/ [in English].

Lo, B. (2019, August). Once more with feeling: Russia and the Asia-Pacific. Analysis. Lowy Institute. Retrieved from http://www.lowyinterpreter.org/publications/once-more-feelingrussia-and-asia-pacific [in English].

Mogato, M. (2017, January 26). Philippines says U.S. military to upgrade bases, defense deal intact. Reuters. Retrieved from https://www.reuters.com/article/us-philippines-usadefence/philippines-says-u-s-military-to-upgrade-bases-defense-deal-intactidUSKBN15A18Z. [in English].

Muraviev, A. (2019, May 6). Understanding Russia's Strategic Engagement with the Indo-AsiaPacific. Asia Pacific Bulletin, 475. Retrieved from https://www.eastwestcenter.org/publications/understanding-russia\%E2\%80\%99s-strategicengagement-the-indo-asia-pacific [in English].

Paal, D. (2019, January 31). America's Future in a Dynamic Asia. Carnegie Endowment for International Peace. Retrieved from https://carnegieendowment.org/2019/01/31/america-sfuture-in-dynamic-asia-pub-78222 [in English].

Pomfret, R. (2018, May). The Eurasian Landbridge and China's Belt and Road Initiative. Vox.o2. Retrieved from https://voxeu.org/article/eurasian-landbridge-and-chinas-belt-androad-initiative [in English].

Rapoza, K. (2018, December 10). Trade War Update: China Subverts Tariffs, Trade Gap Gets Wider. Forbes. Retrieved from https://www.forbes.com/sites/kenrapoza/2018/12/10/tradewar-update-china-subverts-tariffs-trade-gap-gets-wider/\#732b105950e5 [in English].

Stavridis, J. (2019, February 22). China's steady plan to take control of the Asia-Pacific region. Financial Review. Retrieved from https://www.afr.com/world/chinas-steady-plan-to-takecontrol-of-the-asiapacific-region-20190222-h1bl57 [in English].

Stevenson, A. (2018, December 10). Wall St. Rises in Day of Unsteady Trading as Global Markets Drop. The New York Times. Retrieved from https://www.nytimes.com/ 2018/12/10/business/global-markets-wall-street.html [in English].

Taylor, A. (2018, April 13). A timeline of Trump's complicated relationship with the TPP. The Washington Post. Retrieved from https://www.washingtonpost.com/news/worldviews/wp/ 2018/04/13/a-timeline-of-trumps-complicated-relationship-with-the-tpp/ [in English].

Weber, R.N. (2005, September 9). Military-Industrial Complex. Encyclopedia Britannica. Retrieved from https://www.britannica.com/topic/military-industrial-complex [in English].

Wiseman, P., Miller, Z. \& Lucey, C. (2018, December 2). US, China Put Brakes on Trade Dispute with Cease-Fire. Associated Press. Retrieved from https://apnews.com/449e5545c3ob42739934e79ba2429126 [in English].

Анатолій Худолій,

Національний університет «Острозъка академія», Украӥна, 3580о, м. Острог, Рівненсъка обл., вул. Семінарсъка, 2 ORCID: https://orcid.org/oooo-ooo1-8144-126X

\section{Геополітичні та регіональні фактори: США, Китай та РФ: партнери чи конкуренти?}

У статті розалянуто політику Сполучених Штатів Америки, Китайсъкої Народної Республіки та Російсъкої Федерациї в Азійсъко-Тихоокеанському регіоні. Лідерські амбіцї згаданих акторів міжнародних відносин яскраво виявились у конкуренциї згаданих краӥн, особливо в останні кілька років. Виокремлено домінуючі сфери конкурентної боротьби тръох краӥн, зокрема: політична, економічна, війсъкова, технологічна та космічна.

Мета статті - здійснити аналіз американо-китайсъких $i$ російськокитайських відносин в Азійсько-Тихоокеанському регіоні та виявити мотиви 
зовнішньої політики згаданих краӥн. АТР став осердям не лише регіональної, але й світової економічної діяльності в кінці 20-го століття і съогодні економічна діяльність і торгівля у цьому регіоні зростають. Це зумовлює актуальність даного дослідження.

Обидві краӥни, КНР і США претендують на лідерську позицію у регіоні. Упродовж усієї історї̈ існування двох країн двосторонні відносини Китаю та Америки зазнавали підйомів і спадів. Відносини між цими крайнами значно погіриились за останні кілька років. Якщо Б. Обама намагався здійснювати послідовну політику щодо Китаю, то Д. Трамп виявився більш категоричним в оцінці політики Пекіну. За каденцї Д. Трампа розпочинається торгова війна з Китаєм, яка відбилася на всіх сферах двостороннъого співробітнищтва.

Незважаючи на конфронтацію у торговій сфері, Китай, як один із провідних гравців у регіональній, а тепер і в світовій політиці, здійснює активну економічну діяльність. Китай реалізуе свої амбіції у низці проектів, на киталт, «Один пояс, один шлях» тощо. Пекіну тісно в межах регіону, тому він намагається вийти на світову арену, прокладаючи магістралі до Західних крайн і розширюючи географію економічного розвитку. Проте Сполучені Штати сприймають таку політику як виклик ӥхній лідерській позицї̈ у світі.

Окрім економічних існують й інші причини напруження між двома державами. Агресивна політика Китаю по відношенню до краӥн-сусідів щодо територіальних претензій на низку островів у Південно-Китайському морі призвела до напруження у регіоні, погіршенні відносин із сусідами та Сполученими Штатами Америки, які засудили агресію. Змагання за лідерство між суперпотугами відбувається в сфері технологій, де Китай має переваги, оскільки намагається створити квантовий компютер і Америка в цьому плані поступається Китаю. Недоліки у політиці США Китай використовуе на свою користь, розвиваючи російсъкий вектор зовнішнъої політики, співпрацюючи з РФ у кількох сферах: війсъковій, економічній, транспортній, торговіü, енергетичній та інших. Захищаючи зовнішньополітичні інтереси, Пекін і Москва зміцнюють власні позицї̈ у регіоні. Росія також зміцнюе військову присутність в АТР, застосовуючи низку інструментів, від військових навчань до продажу зброї. Окрім Китаю, Росія розвиває війсъкове співробітництво з Шрі-Ланкою та Республікою Фіджі.

Ключові слова: АТР, США, Китай, Росія, лідерство, регіональна політика, регіональні актори 